\title{
Synthesis, Spectral Study and Theoretical Treatment of Some Mixing Ligand Complexes of Quinaldic Acid and 1, 10-Phenathroline
}

\section{Sahar Sabeeh Hassan \\ Sura Khaleel Ibrahim \\ Moiead Salih Mohammed}

Department of Chemistry, College of Science for Woman, University of Baghdad, Baghdad, Iraq

E-mail:saharsabeeh21@yahoo.com

Received 15/3/ 2015

Accepted 28/6/ 2015

c) (i) (9)

NoDerivatives 4.0 International Licens

\begin{abstract}
:
Metal complexes of $\mathrm{Cu}$ (II), Fe (III) and $\mathrm{Mn}$ (II) with Quinaldic acid $\left(\mathrm{L}_{1}\right)$ and 1, 10-Phenathroline $\left(\mathrm{L}_{2}\right)$ are synthesized and characterized by standaral physic- chemical procedures (element analysis, metal analysis, FTIR, Uv-Vis, magnetic moment and conductometeric measurements). On the base of these studies, mononuclear and six coordinated octahedral geometry and nonelectrolyte of these complexes have been proposed. The standard heat of formation $\left(\Delta \mathrm{H}_{\mathrm{f}}^{\mathrm{o}}\right)$ and binding energy $\left(\Delta \mathrm{E}_{\mathrm{b}}\right)$ for the free ligands and their complexes are calculated by using the PM3 method at $273 \mathrm{~K}$ of Hyperchem.-8 program. The complexes are more stable than their ligands. Moreover, the electrostatic potential of free ligands are measured to investigate the reactive site of the molecules, PM3 is used to evaluate the vibrational spectra of the free ligands, the frequencies are obtained approximately agreed with those values experimentally found; in addition, the calculation helps to assign clearly the most diagnostic bands .
\end{abstract}

Key words: Quinaldic Acid, 1, 10-Phenathroline, Mixing Ligand, Hyperchem.-8 Program, Theoretical Treatment.

\section{Introduction:}

Quinaldic acid (QA) and its correspondents offer possible sites for bio-chemically active compounds. They also show wide diversity of medicinal properties that include antitumor [1], antiviral [2], aestrogenic activity [3]. Quinoline carboxylic acid is a strong chelator for many transition metal ions. It also has significant potential applications in the removal and recovery

of $\mathrm{Al}$ (III) ions from acidic environmental sites of waste, an application that is of chief significance because of the role $\mathrm{Al}$ (III) ions play as a neurotoxic contamination and its economic value [4]. Other studies of QA are tested as inhibitors for the corrosion of steel [5], and an established precipitating agent in the gravimetric analysis of metal (II) ions [6]. QA 
usually acts as a bidentate chelating ligand in its some metal (II) complexes [7]. Mixed ligand complexes of QA and pyridine derivatives metabolites formed are important signaling agents in neuronal pathways which are vital to the onset of certain diseases [8]. Growths in iron concentrations and picolinic acid have been perceived in Alzheimer [8]. Analogues 2,2-Bipyridine is identified to make stable chelate complexes even with low valent transition metal ions [9]. Today, it is even one of the most widely used chelate systems in coordination chemistry and in recent years has also become a very popular ligand in supramolecular and macromolecular chemistry[10].

\section{Material and Methods:}

The chemicals used in this work are all of analytical reagent grade. Furthermore, metal salts used in this study include copper chloride dihydrate $\mathrm{CuCl}_{2} \cdot 2 \mathrm{H}_{2} \mathrm{O}$ from Fluka, manganies chloride tetrahydrate $\mathrm{MnCl}_{2} \cdot 4 \mathrm{H}_{2} \mathrm{O}$ from Fluka, and iron trichloride nano hydrate $\mathrm{FeCl}_{3} .9 \mathrm{H}_{2} \mathrm{O}$ from $\mathrm{BDH}$. Ligand $\mathrm{QH}$ from Merk and 1,10-Phenathroline from $\mathrm{RDH}$. The metal analysis is conducted by a Perkin Elmer 5000 Atomic Absorption Spectrophotometer.

Elemental Analysis (CHN) of compounds is prepared by using EM034 mth. FTIR spectra are documented on a Shimadzu 8400 Fourier transform spectrophotometer via using CsI disk in the wave number range of 4000-200 $\mathrm{cm}^{-1}$, and shimadzu Uv-vis 1600A Ultraviolate spectrophotometer is use to record the electronic spectra by using Quartz cell at a wave length range of 200-1100nm. The molar conductance is calculated in DMF as a solvent at room temperature via coring conductivity Meter 220 with Gallencamp M.F.B600.01 as a melting point device and magnetic Susceptibility Balance of Johnson matting catalytic system separation is conducted in room temperature.

\section{Synthesis of Mixed Metal Ligand Complexes:}

The method has been used is general to prepare the new complexes by the reaction of a solution containing the co-ligand phen. $(5 \mathrm{ml})$ of absolute ethanol, and primary ligand QA $(10 \mathrm{ml})$ of the same solvent, are added to a $(5 \mathrm{ml})$ warm ethanol of metal salts in molar ratio 1:1:1 . The mixture undergoes heating and reflux operation with stirring for (1.5-3) hrs. The colored precipitates are filtered then washed for several times with ethanol, recrystallized by ethanol-ether mixture. They are dried by using desiccator.

\section{Programs:}

HyperChem-8 is a sophisticated molecular modeling environment that is known for its quality, flexibility, and ease of use, uniting 3D visualization and animation with quantum chemical calculations, molecular mechanics, and dynamics. It offers ten semi-empirical methods. Some of them have been developed precisely for the description of organic chemistry too, and commonly good for predicting molecular geometry and energetic. They can be used for prediction vibrational modes and transition structures.

\section{Results and Discussion: General:}

The complexes obtained are colored powders stable for a long time in an open atmosphere. The analytical data for the complexes with some physical properties are summed up in Table (1). All the complexes are cautiously soluble in general organic solvents, the melting points demonstrate that all the complexes decompose prior to melting. Analytical data suggest a ratio of 1:1:1 [M: $\mathrm{L}_{1}: \mathrm{L}_{2}$ ] for all metal complexes. Consequently, the format the molar 
conductivity corresponding to the $\mathrm{Cu}$ (II), Mn (II) and Fe (III) complexes presents low values and in this technique a structural formula of non-electrolyte for these complexes can be assigned. The magnetic moment is consistent with low spin around the iron ion and high spin for both Manganese and Copper ions. Octahedral geometries are recommended for the prepared complexes so that the general formula of these complexes can be shown as: $\left[\mathrm{ML}_{1} \mathrm{~L}_{2} \mathrm{Cl}_{\mathrm{x}}\left(\mathrm{H}_{2} \mathrm{O}\right)_{\mathrm{y}}\right] \cdot \mathrm{ZH}_{2} \mathrm{O}$ where $\mathrm{M}=\mathrm{Mn}^{\mathrm{II}}, \mathrm{Cu}^{\mathrm{II}}, \mathrm{Fe}^{\mathrm{III}} ; \mathrm{x}=1,1,2$; $\mathrm{y}=1,1,0 ; \mathrm{Z}=0.5,1,2.5$ separately.

\section{Infrared Spectra:}

The FTIR spectra provide information concerning the nature of the functional group attached to the metal atom. QA may coordinate with metal ions through monodentate, bidentate chelating and bridging according to Nakamato and Deacon\& Philips [11]. The infrared spectrum of the solid state of $\mathrm{QH}$ indicates that it exists in two toutomeric forms sometime as a neutral molecule (quinolin-2-carboxylic acid) and as a Zwitter ion (quinolinium-2carboxylate) [12]. The spectrum of the ligand shows a typical broad band in the range $(3417-2534) \mathrm{cm}^{-1}$ with the its maximum at $2937 \mathrm{~cm}^{-1}$ which refers to the stretching frequency of $v(\mathrm{OH})$ of carboxylic acid[11]. The absence of absorption of these bands in this region in IR spectra for all complexes confirms the complete deprotonation of ligand in these complexes [13]. Further confirmation comes from the absence of $\mathrm{C}-\mathrm{O}-\mathrm{H}$ bending peak for $\mathrm{COOH}$ group at $908 \mathrm{~cm}^{-1}$ [14]. The difference of the value $(\Delta v)$ between the (asy $\mathrm{COO}^{-}$- sym $\mathrm{COO}^{-}$) of all complexes has been compared in order to predict the mode of coordination of metal ions primary ligand HQ as shown in Table (2). The $\Delta v$ for each complex indicates the monodentate coordination of carboxylic group. The nitrogen atom of ligand also has coordinated with metal ions which is confirmed in all complexes by shifting the $\delta$ bending $\mathrm{C}=\mathrm{N}$ and appeared in the range (410-390) $\mathrm{cm}^{-1}$ [15]. Furthermore, new bands appear by appearance of frequencies in the range (520-542), (416-433) and (320-335) $\mathrm{cm}^{-1}$ which is attributed to $v(\mathrm{M}-\mathrm{N}),(\mathrm{M}-\mathrm{O})$ and $(\mathrm{M}-\mathrm{Cl})$ respectively in all complexes. This refers to the ligand which has coordinated as a bidentated with metal ions through oxygen of carboxylic acid and the nitrogen atom [11].Table (2) shows the major bands for phen assigned to the stretching vibrations of $v \mathrm{C}=\mathrm{N}+\mathrm{C}=\mathrm{C}$ which appears at (1616-1419) $\mathrm{cm}^{-1}[11,16$, 17]. All bands shift to higher wave numbers in spectra of all complexes compared with spectrum of the free coligand. This indicates the coordination to metals through the two $\mathrm{Sp}^{2}$ hybridized nitrogen atoms [18]. An additional new band appears in the $265,266 \mathrm{~cm}^{-1}$, this is an additional proof that two nitrogen of co-ligand coordinate with metal ions [16]. A band is observed around (34393309) $\mathrm{cm}^{-1}$ in the spectra of metal complexes which refers to the presence of water molecules in the crystal lattic or coordinate with metal ions [11].

\section{Electronic Spectra and Magnetic Moment:}

Table (3) displays the electronic spectra data of the metal complexes in DMF solvent . The nature of the ligand field around the metal ions has been gathered from the electron spectra.

The electronic spectrum of $\mathrm{L}_{1}$ shows four main bonds that appear at $45045,41666,34843$ and shoulder band at $30487 \mathrm{~cm}^{-1}$ refers to $\pi-\pi^{*}$ and $3 \mathrm{n}-\pi^{*}$ transition respectively [19], while $\mathrm{L}_{2}$ exhibits three bands at 43859, 38022 and $30864 \mathrm{~cm}^{-1}$, due to $\pi \rightarrow \pi^{*}$ and $2 \mathrm{n} \rightarrow \pi^{*}$ transition [17].

Mn(II) complex: In this study, the brown colour of $\mathrm{Mn}$ (II) complex displays two bands at 20408 and 24100 $\mathrm{cm}^{-1}$, spectra assignments are obtained by fitting the observed spectra to 
TanabSugao Diagram for $\mathrm{d}^{5}$ configuration. Table (3) shows the values of $v_{1}, \mathrm{~B}^{\prime}, \beta$ and $10 \mathrm{Dq}$ computed there form [20].

Two observations have to be pointed out : (I) a series of some very weak, and narrow bands have been observed in manganese spectrum. This is expected because only sextet term of the $\mathrm{d}^{5}$ configuration in Oh stereochemistry is the ${ }^{6} \mathrm{~A}_{1} \mathrm{~g}$, consequently, there can be no spin - allowed transition [20,21].

Furthermore, the energies of the ${ }^{4} \mathrm{Eg}(\mathrm{G})+{ }^{4} \mathrm{~A}_{1} \mathrm{~g}(\mathrm{G})$ terms do not change much relative to the ${ }^{6} \mathrm{~A}_{1} \mathrm{~g}$ ground term as 10Dq change, as seen from the T. S. D. Therefore, bands corresponding to the transition between the ground term and these two terms are not appreciably broadened by vibronic coupling [20]. (II) The value of the nephelauxetic ratio $\beta$ is evaluated as the ratio of the term separation in the complex. The electronic spectrum coupled with magnetic 4.78BM supports the suggested geometry of this complex [22].
Fe (III) complex: The magnetic measurement shows that iron in its brownish red coloure to be low spin state, which is $2.36 \mathrm{BM}$, of $\mathrm{d}^{5}$ configuration. This suggestion is supported by the number of maxima observed in the electronic spectrum of the complex, which shows three maxima at 10869,15384 and $19841 \mathrm{~cm}^{-1}$ may be assigned to the ${ }^{2} \mathrm{~T}_{2} \mathrm{~g} \rightarrow{ }^{4} \mathrm{~T}_{1} \mathrm{~g},{ }^{2} \mathrm{~T}_{2} \mathrm{~g} \rightarrow{ }^{4} \mathrm{~T}_{2} \mathrm{~g}$ and ${ }^{2} \mathrm{~T}_{2} \mathrm{~g} \rightarrow{ }^{2} \mathrm{~A}_{2} \mathrm{~g}+{ }^{2} \mathrm{~T}_{1} \mathrm{~g}$ transition[20,23] as shown in Table (3). The $v_{1}$ reach parameter $\mathrm{B}^{\prime}$ and the value of $10 \mathrm{Dq}$ are calculated by reference to T. S. D. for $\mathrm{d}^{5}$ configuration. The value of $\frac{55 \mathrm{~B}^{\prime}}{2}$, which further indicates that the complex is low spin $[21,24]$.

$\mathrm{Cu}$ (II) complex: Electronic spectrum of green complex displayed band at $15814 \mathrm{~cm}^{-1}$ which is assigned to ${ }^{2} \mathrm{Eg} \rightarrow{ }^{2} \mathrm{~T}_{2} \mathrm{~g}$ transition, the broadness of the band is due to the ligand field and the Jahn- Teller effect, This absorption prefers the distortion Oh geometry [25]. Moreover, the magnetic moment is 2.1 $\mathrm{BM}$, this value lies within the expected for one electron of mononuclear octahedral [26].

Table (1): Some Analytical and Physical Data for the Ligands and Their Metal Complexes

\begin{tabular}{|c|c|c|c|c|c|c|c|c|}
\hline \multirow{2}{*}{ Compound } & \multirow{2}{*}{ Color } & \multirow{2}{*}{$\begin{array}{c}\text { M.P } \\
{ }^{\circ} \mathrm{C} \\
\end{array}$} & \multirow{2}{*}{$\begin{array}{c}\text { Yield } \\
\%\end{array}$} & \multirow{2}{*}{$\begin{array}{l}\text { M.wt } \\
\text { g.mol }{ }^{-1}\end{array}$} & \multicolumn{4}{|c|}{ Elemental analysis \% Found (calc.) } \\
\hline & & & & & $\mathrm{C}$ & $\mathrm{H}$ & $\mathrm{N}$ & $\mathrm{M}$ \\
\hline $\mathrm{C}_{10} \mathrm{H}_{7} \mathrm{NO}_{2}(\mathrm{QH})\left(\mathrm{L}_{1}\right)$ & White & $154-156$ & -- & 173.17 & & & & \\
\hline $\mathrm{C}_{12} \mathrm{H}_{8} \mathrm{~N}_{2} \cdot \mathrm{H}_{2} \mathrm{O}\left(\mathrm{L}_{2}\right)$ & White & $100-102$ & -- & 198.0 & & & & \\
\hline$\left[\mathrm{MnL}_{1} \mathrm{~L}_{2} \mathrm{ClH}_{2} \mathrm{O}\right] .1 / 2 \mathrm{H}_{2} \mathrm{O}$ & $\begin{array}{c}\text { Light } \\
\text { Brown } \\
\end{array}$ & $300 d$ & 78 & 487.5 & $\begin{array}{c}53.52 \\
(54.15) \\
\end{array}$ & $\begin{array}{c}2.92 \\
(3.89) \\
\end{array}$ & $\begin{array}{c}7.93 \\
(8.61) \\
\end{array}$ & $\begin{array}{c}10.58 \\
(11.23) \\
\end{array}$ \\
\hline$\left[\mathrm{FeL}_{1} \mathrm{~L}_{2} \mathrm{Cl}_{2}\right] .5 / 2 \mathrm{H}_{2} \mathrm{O}$ & $\begin{array}{c}\text { Brownish } \\
\text { Red }\end{array}$ & $180 \mathrm{~d}$ & 93 & 542 & $\begin{array}{c}47.23 \\
(48.708) \\
\end{array}$ & $\begin{array}{c}2.99 \\
(3.87) \\
\end{array}$ & $\begin{array}{c}6.54 \\
(7.74) \\
\end{array}$ & $\begin{array}{c}11.02 \\
(10.33) \\
\end{array}$ \\
\hline$\left[\mathrm{CuL}_{1} \mathrm{~L}_{2} \mathrm{ClH}_{2} \mathrm{O}\right] \cdot \mathrm{H}_{2} \mathrm{O}$ & Green & $192 \mathrm{~d}$ & 88 & 469 & $\begin{array}{c}55.37 \\
(56.28) \\
\end{array}$ & $\begin{array}{c}3.96 \\
(4.26) \\
\end{array}$ & $\begin{array}{c}8.31 \\
(8.95) \\
\end{array}$ & $\begin{array}{c}12.57 \\
(13.53) \\
\end{array}$ \\
\hline
\end{tabular}

d:decomposition degree

Table (2): Diagnostic FT.IR Bands of the Ligands and Their Metal Complexes $\left(\mathrm{cm}^{-1}\right)$

\begin{tabular}{|c|c|c|c|c|c|c|c|c|}
\hline Compound & $v_{\text {asy }} \cdot \mathrm{COO}^{-}$ & $v_{\mathrm{sym}} \cdot \mathrm{COO}^{-}$ & $v_{\mathrm{C}=\mathrm{O}}$ & $v_{\mathrm{C}=\mathrm{C}+\mathrm{C}=\mathrm{N}}$ & $v_{\mathrm{M}-\mathrm{N}}$ & $v_{\mathrm{M}-\mathrm{O}}$ & $v_{\mathrm{M}-\mathrm{N} \text { phe }}$ & Others \\
\hline $\mathrm{C}_{10} \mathrm{H}_{7} \mathrm{NO}_{2}(\mathrm{QH})\left(\mathrm{L}_{1}\right)$ & 1580 & 1390 & 1697 & $\begin{array}{l}1604,1534, \\
1508,1473\end{array}$ & -- & -- & -- & -- \\
\hline $\mathrm{C}_{12} \mathrm{H}_{8} \mathrm{~N}_{2} \cdot \mathrm{H}_{2} \mathrm{O}(\mathrm{phe})\left(\mathrm{L}_{2}\right)$ & -- & -- & -- & $\begin{array}{l}1616,1589, \\
1558,1504, \\
1446,1419\end{array}$ & -- & -- & -- & $v_{\mathrm{H} 2 \mathrm{O}}=3387$ \\
\hline$\left[\mathrm{MnL}_{1} \mathrm{~L}_{2} \mathrm{ClH}_{2} \mathrm{O}\right] \cdot 1 / 2 \mathrm{H}_{2} \mathrm{O}$ & 1597 & 1394 & 1695 & $\begin{array}{l}1622,1597, \\
1560,1516, \\
1463,1423\end{array}$ & 542 & 416 & 265 & $\begin{array}{c}v_{\mathrm{H} 2 \mathrm{O}}=3309 \\
\delta_{\mathrm{H} 2 \mathrm{O}}=860 \\
\mathrm{MnCl}=335\end{array}$ \\
\hline$\left[\mathrm{FeL}_{1} \mathrm{~L}_{2} \mathrm{Cl}_{2}\right] .5 / 2 \mathrm{H}_{2} \mathrm{O}$ & 1591 & 1385 & 1695 & $\begin{array}{l}1625,1591, \\
1560,1504, \\
1425,1462\end{array}$ & 520 & 433 & 266 & $\begin{array}{c}v_{\mathrm{H} 2 \mathrm{O}}=3439 \\
\delta_{\mathrm{H} 2 \mathrm{O}}=848 \\
\mathrm{FeCl}=330\end{array}$ \\
\hline$\left[\mathrm{CuL}_{1} \mathrm{~L}_{2} \mathrm{ClH}_{2} \mathrm{O}\right] \cdot \mathrm{H}_{2} \mathrm{O}$ & 1585 & 1377 & 1695 & $\begin{array}{l}1629,1585, \\
1568,1514, \\
1462,1421\end{array}$ & 536 & 430 & 265 & $\begin{array}{c}v_{\mathrm{H} 2 \mathrm{O}}=3342 \\
\delta_{\mathrm{H} 2 \mathrm{O}}=854 \\
\mathrm{CuCl}=321\end{array}$ \\
\hline
\end{tabular}


Table (3): Electronic Spectra Data and Their Assignment of the Prepared New Complexes

\begin{tabular}{|c|c|c|c|c|c|c|c|c|}
\hline Compound & $\begin{array}{c}\text { Bands, } \\
\mathrm{cm}^{-1}\end{array}$ & Assignment & $\mathrm{B}^{0} \mathbf{c m}^{-1}$ & Dq/ B & $\begin{array}{c}B^{\prime} \\
\mathbf{c m}^{-1}\end{array}$ & $\boldsymbol{\beta}$ & $\begin{array}{c}\text { 10Dq } \\
\mathrm{cm}^{-1}\end{array}$ & $\begin{array}{c}\text { Separation } \\
\text { Term }\end{array}$ \\
\hline$\left[\mathrm{MnL}_{1} \mathrm{~L}_{2} \mathrm{ClH}_{2} \mathrm{O}\right] \cdot 1 / 2 \mathrm{H}_{2} \mathrm{O}$ & $\begin{array}{c}11457 \text { (cal.) } \\
20408 \\
24100\end{array}$ & $\begin{array}{l}{ }^{6} \mathrm{~A}_{1} \mathrm{~g} \\
{ }^{6} \mathrm{~A}^{1} \mathrm{~g} \longrightarrow{ }^{4} \mathrm{~T}_{1} \mathrm{~g}(\mathrm{G}) \\
{ }^{4} \mathrm{~T}_{2} \mathrm{~g}(\mathrm{G}) \\
{ }^{6} \mathrm{~A}_{1} \mathrm{~g} \longrightarrow{ }^{4} \mathrm{~A}_{1} \mathrm{~g}+{ }^{4} \mathrm{Eg}(\mathrm{G})\end{array}$ & 860 & $1.23 \mathrm{CB}$ & 745 & 0.87 & 9952 & 11325 \\
\hline$\left[\mathrm{FeL}_{1} \mathrm{~L}_{2} \mathrm{Cl}_{2}\right] .5 / 2 \mathrm{H}_{2} \mathrm{O}$ & $\begin{array}{c}10869 \\
11039(\mathrm{cal}) \\
15384 \\
19841 \\
\end{array}$ & 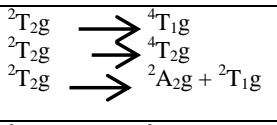 & 1300 & $3.5 \mathrm{CB}$ & 665 & 0.5 & 23275 & 9975 \\
\hline$\left[\mathrm{CuL}_{1} \mathrm{~L}_{2} \mathrm{ClH}_{2} \mathrm{O}\right] \cdot \mathrm{H}_{2} \mathrm{O}$ & 15184 & ${ }^{2} \mathrm{Eg} \longrightarrow{ }^{2} \mathrm{~T}_{2} \mathrm{~g}$ & & & & & & \\
\hline
\end{tabular}

\section{Theoretical Study:}

(I) The program HyperChem-8 is used for the semi- empirical calculation at optimized geometries energies. The results of PM3 method of calculation in gas phase for heat of formation and ligand and its complexes are calculated and tabulated in (Table 4). Theoretically calculated wave numbers for these ligands show some deviations from the experimental values. These deviations are generally acceptable in theoretical calculation [27] and are described in Table (4): Conformation Energetic (in KJ.mol ${ }^{-1}$ ) for the Ligands and Their Metal Complexes

\begin{tabular}{|c|c|c|}
\hline \multirow{2}{*}{ Compound } & \multicolumn{2}{|c|}{ PM3 } \\
\cline { 2 - 3 } & $\Delta \mathbf{H}^{\circ}{ }_{f}$ & $\Delta \mathbf{E}_{\mathrm{b}}$ \\
\hline $\mathrm{L}_{1}$ & -160.619 & -9807.802 \\
\hline $\mathrm{L}_{2}$ & 297.733 & -10971.849 \\
\hline$\left[\mathrm{MnL}_{1} \mathrm{~L}_{2} \mathrm{ClH}_{2} \mathrm{O}\right] .1 / 2 \mathrm{H}_{2} \mathrm{O}$ & -809.750 & -22598.260 \\
\hline$\left[\mathrm{FeL}_{1} \mathrm{~L}_{2} \mathrm{Cl}_{2}\right] .5 / 2 \mathrm{H}_{2} \mathrm{O}$ & -1516.637 & -22873.471 \\
\hline$\left[\mathrm{CuL}_{1} \mathrm{~L}_{2} \mathrm{ClH}_{2} \mathrm{O}\right] . \mathrm{H}_{2} \mathrm{O}$ & -465.172 & -22308.075 \\
\hline
\end{tabular}
(Table 5).

Table (5): A Comparison between Experimental and Theoretical Vibrational Frequencies for the Ligands and Their Metal Complexes (cm-1)

\begin{tabular}{|c|c|c|c|c|c|c|}
\hline Compound & $v_{\text {asy }} \mathrm{COO}^{-}$ & $\mathrm{v}_{\mathrm{sym}} \mathrm{COO}^{-}$ & $\boldsymbol{v} \mathbf{C}=\mathbf{O}$ & vM-N & vM-O & vM-Nphe \\
\hline $\mathbf{L}_{1}$ & $\begin{array}{c}* 1580 \\
* * 1516 \\
* * *-4.05\end{array}$ & $\begin{array}{c}* 1390 \\
* * 1245.69 \\
* * *-11.58\end{array}$ & $\begin{array}{c}* 1697 \\
* * 1881.84 \\
* * * 10.89\end{array}$ & --------- & --------- & -------- \\
\hline $\mathbf{L}_{2}$ & ------- & ------ & ------ & --------- & -------- & --------- \\
\hline$\left[\mathrm{MnL}_{1} \mathrm{~L}_{2} \mathrm{ClH}_{2} \mathrm{O}\right] \cdot 1 / 2 \mathrm{H}_{2} \mathrm{O}$ & $\begin{array}{c}* 1597 \\
* * 1485.17 \\
* * *-7.00\end{array}$ & $\begin{array}{c}* 1394 \\
* * 1425.98 \\
* * * 2.29 \\
\end{array}$ & $\begin{array}{c}* 1695 \\
* * 1855.64 \\
* * * 9.47 \\
\end{array}$ & $\begin{array}{c}* 542 \\
* * 529.47 \\
* * *-2.31\end{array}$ & $\begin{array}{c}* 416 \\
* * 374.07 \\
* * *-10.07\end{array}$ & $\begin{array}{c}* 265 \\
* * 254.76 \\
* * *-3.86\end{array}$ \\
\hline$\left[\mathrm{FeL}_{1} \mathrm{~L}_{2} \mathrm{Cl}_{2}\right] .5 / 2 \mathrm{H}_{2} \mathrm{O}$ & $\begin{array}{c}* 1591 \\
* * 1583.56 \\
* * *_{-} 0.46 \\
\end{array}$ & $\begin{array}{c}* 1385 \\
* * 1428.65 \\
* * * 3.15 \\
\end{array}$ & $\begin{array}{c}* * 1695 \\
* * 1884.47 \\
* * * 11.17 \\
\end{array}$ & $\begin{array}{c}* 520 \\
* * 529.75 \\
* * * 1.875 \\
\end{array}$ & $\begin{array}{c}* 433 \\
* * 452.25 \\
* * * 4.44\end{array}$ & $\begin{array}{c}* 266 \\
* * 259.44 \\
* * *-2.46 \\
\end{array}$ \\
\hline$\left[\mathrm{CuL}_{1} \mathrm{~L}_{2} \mathrm{ClH}_{2} \mathrm{O}\right] \cdot \mathrm{H}_{2} \mathrm{O}$ & $\begin{array}{c}* 1585 \\
* * 1525.76 \\
* * *-3.73\end{array}$ & $\begin{array}{c}* 1377 \\
* * 1344.40 \\
* * *-2.42\end{array}$ & $\begin{array}{c}* 1695 \\
* * 1863.57 \\
* * * 9.94\end{array}$ & $\begin{array}{c}* 536 \\
* * 586 \\
* * * 9.32\end{array}$ & $\begin{array}{c}* 430 \\
* * 432.23 \\
* *-0.518\end{array}$ & $\begin{array}{c}* 265 \\
* * 266.87 \\
* * * 0.705\end{array}$ \\
\hline
\end{tabular}

*Experimental frequencies

$* *$ Theoretical frequencies

$* * *$ Error $\%$

(II) Electrostatic potential: It designates the interaction of energy of the molecular system with a positive charge point, that is the reason why it is practical for finding sites of reaction in molecule positive charge species. They tend to attack a molecule wherever the E.P is powerfully negative electrophilic attach [20]. The E.P of the free ligand is measured and plotted as 2D and 3D contour to inspect the reactive sites of the molecules shown in (Figure3). The results of calculation illustrate that the LUMO of transition metal ion choose to react with the HOMO of donor atoms in ligands, as shown in Figure (4) via adopting Hyperchem.-8 program. 


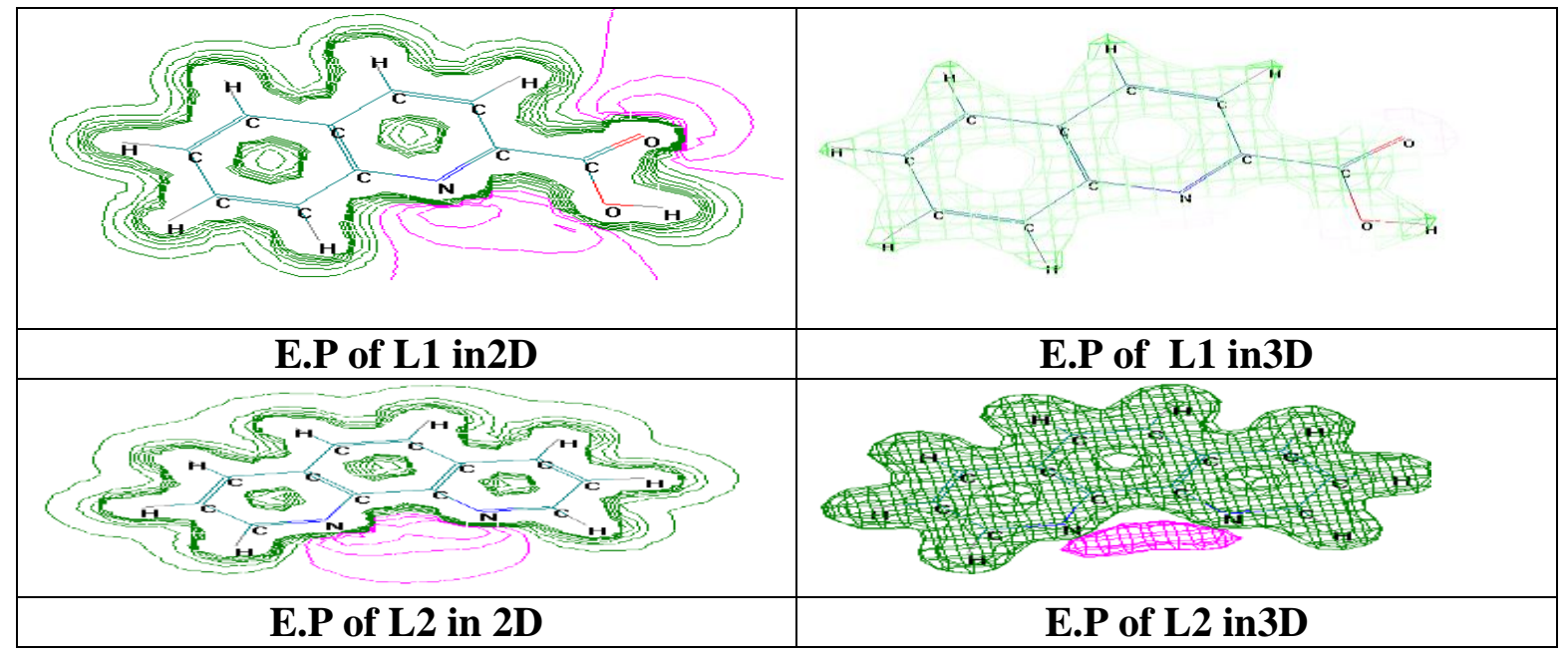

Fig. (3): Electrostatic Potential as 2D\&3D Counters for L1 and L2

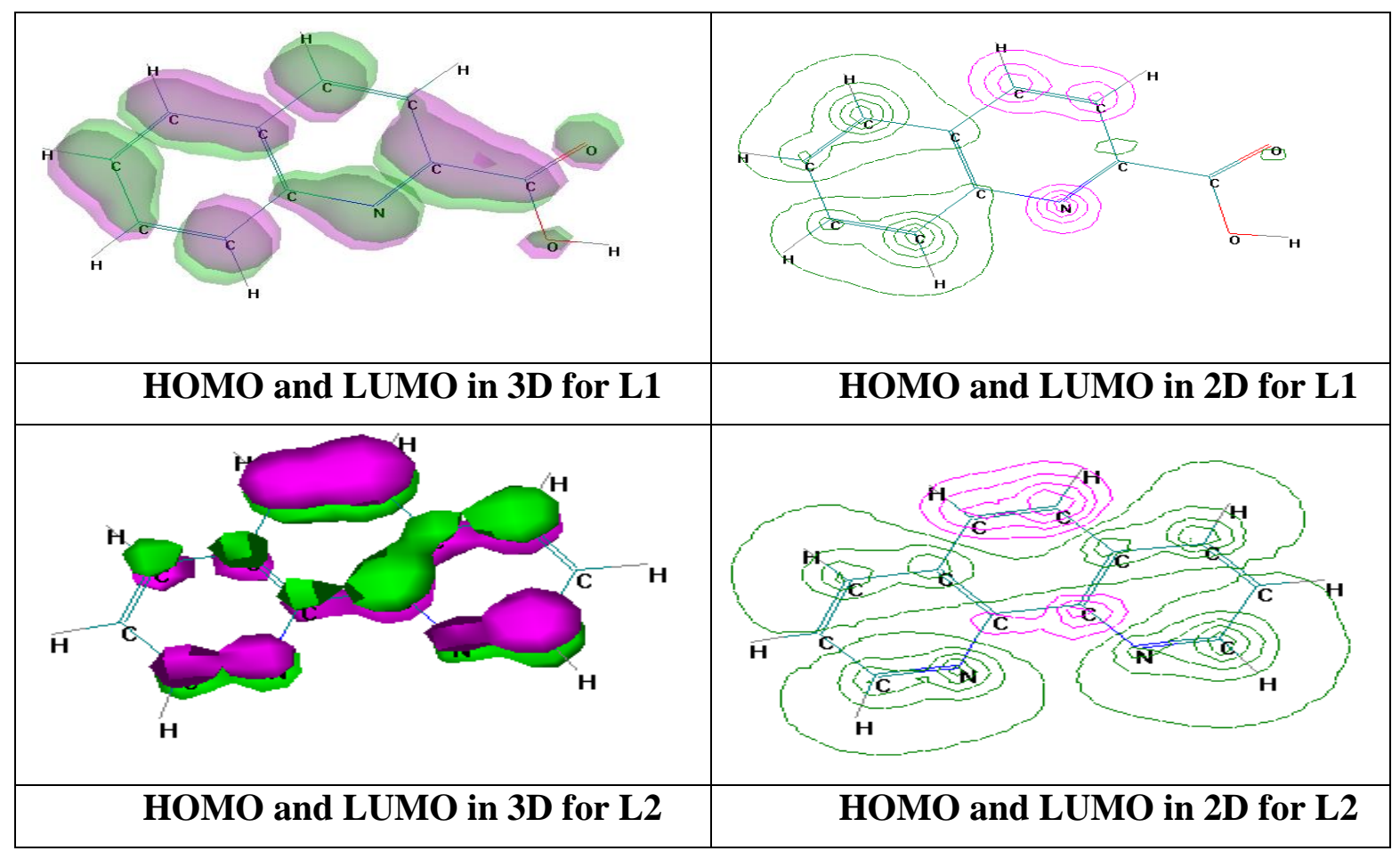

Fig. (4): HOMO and LUMO Sites for the L1 and L2

(III) Optimized geometries and energy of metal complexes for the ligand: Theoretically probable structures of metal complexes with ligand have been calculated to find the most possible model building stable structure. The shapes appearing in Figure (5) indicate the calculation optima geometries for the imine and its complexes. The outcomes of PM3 methods of calculation in gas phase for $\Delta \mathrm{H}_{\mathrm{f}}{ }^{\mathrm{o}}$ and $\Delta \mathrm{E}_{\mathrm{b}}$ are tabulated in Table (4) for Fe (III), Mn (II) and Cu (II) complexes. 


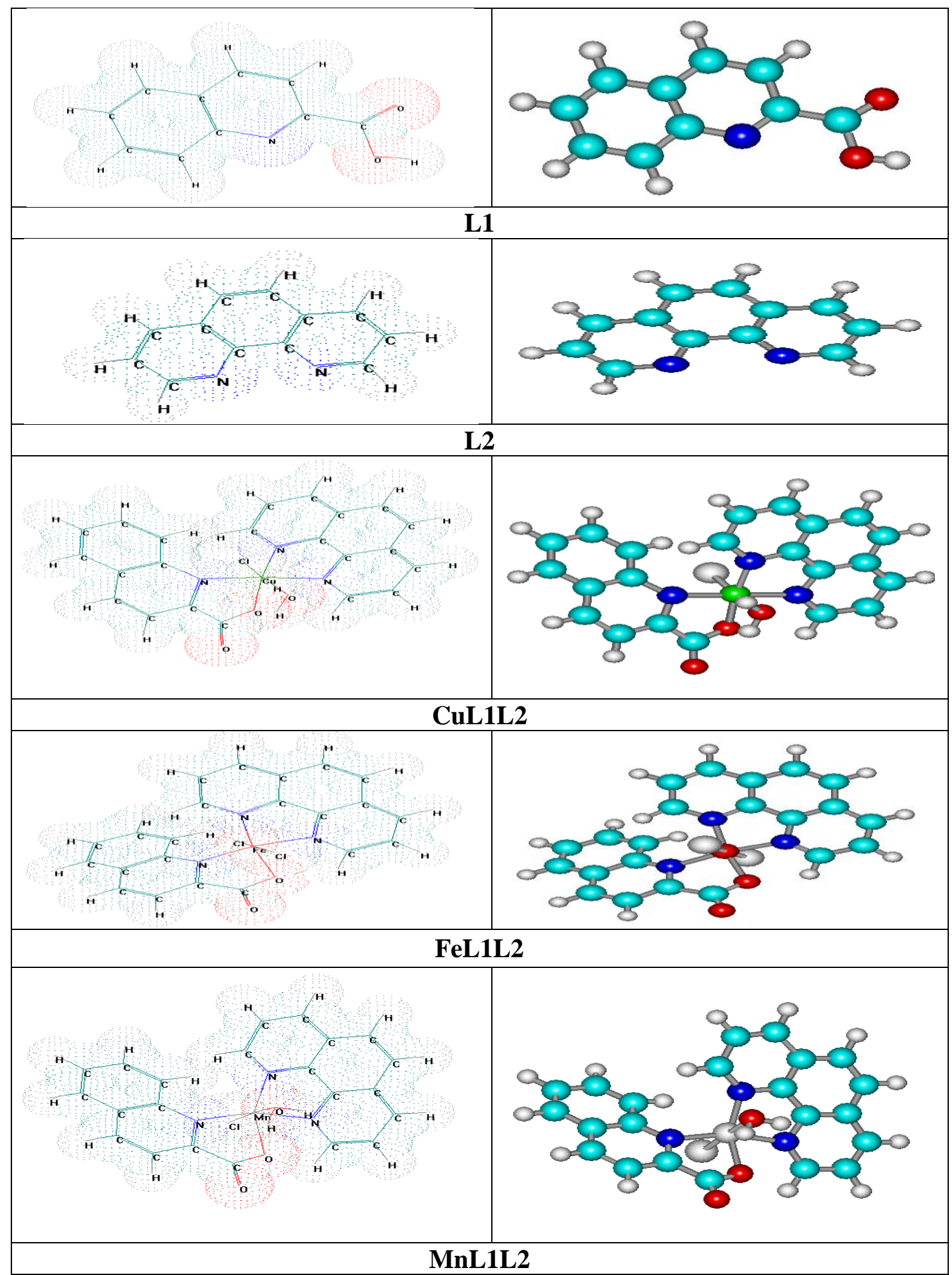

Fig.(5): Conformation Structure of Ligands and Their Metal Complexes Using Hyperchem.-8. Program 


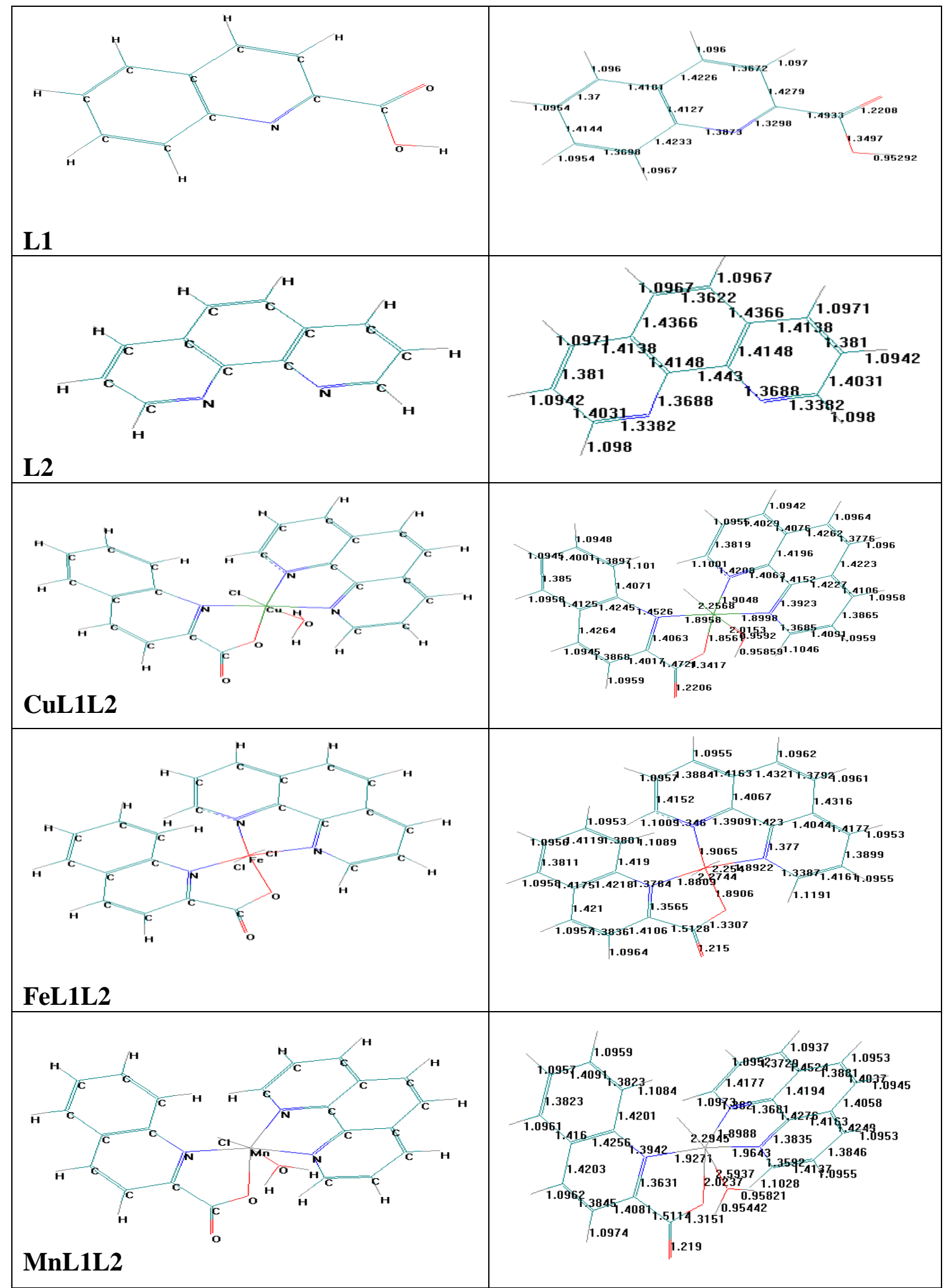

Fig. (6): Bond length of Ligands and Their Metal Complexes Using Hyperchem.-8. Program. 


\section{References:}

[1] A)Atwell, G.; Baguly, B. C.and Denny, W. A. 1989. Potential antitumor agents. 57. 2Phenylquinoline-8-carboxamides as minimal DNA-intercalating antitumor agents with in vivo solid tumor activity. J. Med. Chem. 32 (2):396401.

B) Feng, X.U.;Ding, Q.; Yang, K. and Jing, W. G. 2006. Synthesis of $11 \mathrm{H}-$ Indeno [1, 2-b] quinolines via the Friedländer Reaction. Chinese. Chem. Lett. 17 (2): 187- 190.

C) Srivastava, S. K.; Jha, A.; Agarwal, S. K.; Mukherjee, R. and Burman ,A. C. 2007. Synthesis and StructureActivity Relationships of Potent Antitumor Active Quinoline and Naphthyridine Derivatives. Anti. Cancer Agent Med. chem.7 (6): 685709.

[2]Dayam, R.; Al-Mawsawi, L. Q.; Zawahir, Z.; Witrvroum, M.; Debyser, Z. and Neamat, N. 2008.Quinolone 3-Carboxylic Acid Pharmacophore: Design of Second Generation HIV-1 Integrase Inhibitors. J. Med. Chem. 51 (5): $1136-1144$.

[3]Shi, F.; Zhang, S.; Wu, S. S.; Gao, Y. and Tu, S. 2011. A diversity-oriented synthesis of pyrazolo[4,3-f]quinoline derivatives with potential bioactivities via microwave-assisted multicomponent reactions. J. Mol. Divers. 15 (2): 497-505.

[4]Olmstead, W.; Li, M. M.; Miggins, D. and Fish, R. H. 1996.Synthesis and Structural Studies of Metal Complexes of the Biological Ligand 2-Quinaldic Acid: Utilization of the Polymer Pendant Analog PS-2-QA for Selective Aluminum Ion Removal from Aqueous Solution. Inorg. Chem. 35(1): 51-55.

[5]EnoEbenso, E.; ImeObot, B. and Murulana. L. C. 2010. Quinoline and its Derivatives as Effective Corrosion
Inhibitors for Mild Steel in Acidic Medium. Int. J. Electrochem. Sci, 5 (1):1574-1586.

[6]Vogel, A. 1962. Textbook of Quantitative Inorganic Analysis $3^{\text {rd }}$ ed., Longman, London.

[7]Allen, F. H. 2002. The Cambridge Structural Database: a quarter of a million crystal structures and rising.Acta Crystalloger. B58: 380388.

[8]Houghton, D. T.;Gydesen, N. W.;Arulsamy, N. and Mark. Mehn, P. 2010. Synthesis and Characterization of Iron (II) Quinaldate Complexes. Inorg. Chem. 49 (3):879-887.

[9]A) Kinnunen, T. J. J.; Haukka, M.; Pesonen E and Pakkanen, T. A. 2002. Ruthenium complexes with 2, 2'-, 2 , 4'- and 4,4'-bipyridine ligands: The role of bipyridine coordination modes and halide ligands. J. Organo. Chem., 655 (1-2): 31-38.

B) Ardon, M.; Hogarth, G. and Oscroft, D. T. W. 2004. Organometallic chemistry in a conventional microwave oven: the facile synthesis of group 6 carbonyl complexes. J. Organo. Chem. 689 (15):2429-2435.

[10]A) Schubert, U. S. and Eschbaumer, C. 2002. Macromolecules containing bipyridine and terpyridine metal complexes: towards metallosupramolecular polymers. Angew. Chemie. International Edition 41 (16):2892-2926.

B) Kaes, C.; Katz, A. and Hosseini, M. W. 2000. Bipyridine: the most widely used ligand. A review of molecules comprising at least two 2, 2'bipyridine units.Chem. Rev. 100 (10):3553-90.

[11]A) Deacon, G. B. and Phillips, R. J. 1980. Relationships between the Carbon-Oxygen stretching frequencies of Carboxylate complexes and the type of 
carboxylate coordination. Coord. Chem. Rev., 33:227-250.

B) Nakamato, N. 2009. Infrared and Raman Spectra of Inorganic and Coordination Compounds. John Wiley \& Sons, Inc. $6^{\text {th }}$ Ed., New Jersey.

[12]McCleverty, J. A.; Gill, S. A.; Kowalski, R. S.Z. and Bially, N. A.1982. Aspects of the inorganic chemistry of rubber vulcanisation. Part 3. Anionic cadmium complexes derived from dialkyldithiocarbamates, 2-mercaptobenzothiazole and its derivatives, and dialkyl dithiophosphates, and the crystal and molecular structures of [NBun4] [Cd (S2CNEt2)3], [NEt4] [Cd (C7H4NS2)3], and [NMe4] [Cd \{S2P(OPri) 2\}3]. J.Chem. Soc. Dalton Trans, 3(9):493-503.

[13]A) Zhang, G. Q.; Wang, Q.; Qian, Y.; Yang, G. Q. and Ma,J. S. 2006. Synthesis, characterization and photoluminescence properties of two new europium (III) coordination polymers with 3D open framework. J. Mole. Struc. 796(1-3):187-194.

B) Du, M.; Zou, R.; Zhong, R. and Xu, Q. 2008. Hydrothermal synthesis, crystal structures and properties of new FeII, CoII, NiII, and ZnII complexes with 6quinolinecarboxylate: Interplay of coordinative and noncovalent interactions Inorg. Chem. Acta. 361(5):1555-1561.

[14]A) Ye, Q.; Chen, X.; Song, Y.;Wang, X.; Zhang, J.; Xiong, R.; Fun, H. and You, X. 2005. A blue fluorescent $\mathrm{Cd}$ (II) coordination polymer with 3, 5- diaminobenzoic acid ligand: synthesis, crystal structure and fluorescent property. Inorg. Chem. Acta, 358(4):12581262.

B) Zhange, Y. N.; Liu, J. Q.; Wang, T.; Wen, G. L.; Yang, G. P.; Wang, Y. Y. and Shi, Q. Z. 2008. Design and syntheses of two novel Mn (II) and
$\mathrm{Cu}$ (II) complexes with 2,2biquinoline-4,4'- dicarboxylate and $\mathrm{N}$-containing bidentate co-ligand. J. Molec. Stru. 878:116-123.

[15]Żurowska, B. and Mroziński, J. 2005. Isomeric forms of $\mathrm{Cu}$ (quinoline-2-carboxylate) $\quad 2 . \mathrm{H}_{2} \mathrm{O}$ compound: Spectroscopic, and magnetic properties. J. Materials Science. Poland, 23 (3): 737-744.

[16]Stuart, B. 2004 .Infrared Spectroscopy. Jon Wiley and Sons Ltd, England .

[17]Silverstein, R. M.; Bassler, G. C. and Morill, T. C. 1981. SpectroChemitric Identification of Organic Chemistry. Jon Wiley and Sons, England.

[18]Li, F. H.; Zhao, G. H.; Wu, H. X.; Lin ,H.; Wu, X. X.; Zhu, S. R. and Lin, H. K. 2006. Synthesis, characterization and biological activity of lanthanum (III) complexes containing 2-methylene-1, 10phenanthroline units bridged by aliphatic diamines. J. Inorg. Biochem. 100:36-43.

[19]Imam, H.; Kumar, B. and Shafayat, M. D. 2011. Mixed Ligand Complexes of Transition Metal Chelates of 1-nitroso-2-naphthol and 8-hydroxyquinoline with Picolinic Acid and Quinaldinic acid. Orien J. Chem. 27 (1):287-291.

[20]Figgis, B. and Hitchman, M. 2000.Ligand Field Theory and Its Applications. Wiley, New York.

[21]Lever, A. B. P. 1984. Inorganic Electronic Spectroscopy. $2^{\text {nd }}$ edition, New York.

[22]Singh, N. and Anu Singh, J. 2012. Magnetic and Spectroscopic Studies of the Synthesized Metal Complexes of Bis(Pyridine-2- carbo) Hydrazide and Their Antimicrobial Studies. Eur.J. Chem 9 (4):1835-1842.

[23]Cotton, F. A.; Wilkinson, G.; Murillo, A. C. and Bochmann, B. 2008. Advanced inorganic chemistry. $7^{\text {th }}$ ed. Wiley. V. C. H. New York. 
[24]Alias, M. F. 2002. Synthesis, Structural and antibacterial Studies of Silver(I) and Iron(III) Chelates of Amino Mercapto Triazole and Palladium(II) Chelate of 2-Propenyl Mercapto Triazole. Ibn Al-Haitham J. for Pure and Appl. SCI,15(1):77-86

[25]Alias, M. F.; Huda, K. and Carolin,Sh. 2014. Synthesis, physical characterization and biological evaluation of Schiff base M (II) complexes.J. of the association of Arab Universities for Basic and Applied Science 15:28-34.
[26]Yousif, I. Q. and Alias, M. F. 2013. Synthesis, Structural Study, antimicrobial Activity and Theoretical Treatment of 3d-metal Complexes involving Schiff Base of Piperonal Derivative. AJPS,13(1):113.

[27]Alias, M. F.; Yousif, I. Q and Ibrahim, S. Kh. 2013. Spectroscopic Characterization and Antimicrobial Activities of Som Heavy Metals Complexes of 2-hydroxy phenyl piperonalidene. J. Baghdad for Sci. 10(3):627-637.

\section{تحضير و دراسة طيفية ومعالجة نظرية لبعض معقدات مزيج ليكاندات حامض

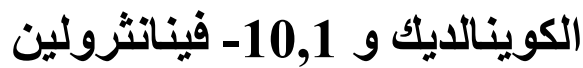

مؤيد صالح محمد

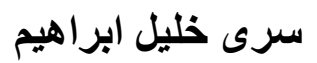

قسم الكيمياء، كلية العلوم للبنات، جامعة بغداد، بغداد، العراق

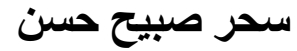

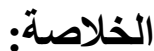

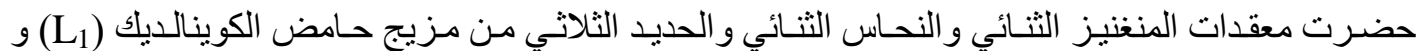

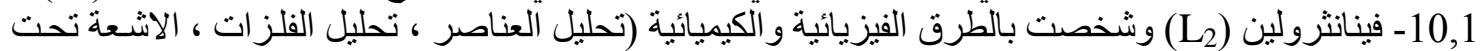

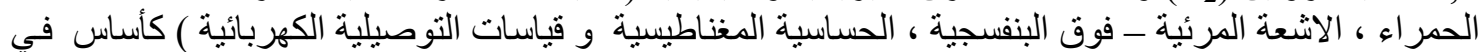

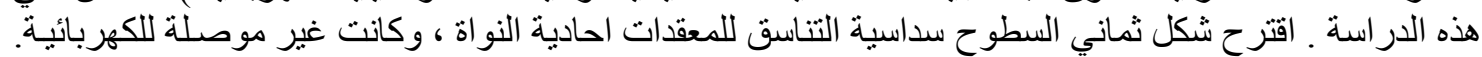
تم حساب حر ارة التكوين وطاقة التآصـر لليكاندات الحرة ومعقدات التها بأستخدام طريقة ال

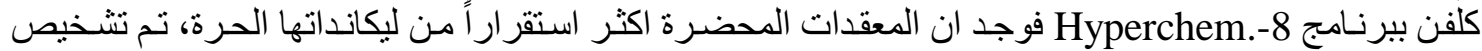
المو اقع الفعالة للجزبئات باستخدام طريقة PM3 لحساب ترددات الاهنز از لليكاندات الحرة فكانـ النتائج متو افقة تقريبا مع القيم العملية بالاضافة الى ذلك ان الحسابات النظرية تساعد في تشخيص معظم الحزم بشكل ادق .

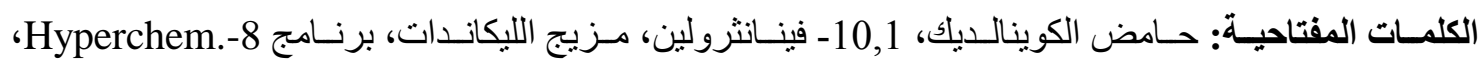

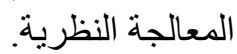

